\title{
Parvovirus infection associated with aplastic crisis in a patient with HEMPAS
}

\author{
N C WEST,* R E MEIGH, $\dagger$ M MACKIE, ${ }^{*}$ M J ANDERSON $\ddagger$ \\ From the Departments of *Haematology and $\dagger$ Medical Microbiology, Royal Liverpool Hospital, Liverpool, \\ and the $\ddagger$ Department of Medical Microbiology, University College, London
}

SUMMARY An aplastic crisis associated with parvovirus infection occurred in a patient suffering from hereditary erythrocytic multinuclearity associated with a positive acidified (Hams) test (HEMPAS). This case emphasises that any patient who has a shortened red cell survival is succeptible to an aplastic crisis induced by parvovirus.

In 1981 Serjeant in Jamaica $^{1}$ and Pattison in the United Kingdom ${ }^{2}$ established an association between parvovirus infection and aplastic crisis in children suffering from sickle cell anaemia. Similar cases associated with parvovirus infection have been described in subjects with hereditary spherocytosis, ${ }^{3-5}$ pyruvate kinase deficiency, ${ }^{6}$ and thalassaemia intermedia. ${ }^{7}$ Aplastic crises in haemolytic anaemias are probably due to a single transmissible agent, the human serum parvovirus. ${ }^{8}$

Between $25 \%$ and $70 \%$ of adults in Europe and the United States of America have evidence of past parvovirus infection, ${ }^{9}$ the acquisition of the antibody occurring most commonly between 4 and 10 years of age. ${ }^{10}$ The most common clinical manifestation of human serum parvovirus infection is erythema infectiosum, a mild illness, the common presenting symptom of which is an erythematous rash; and this is often complicated in adults by arthralgia or arthritis. ${ }^{1112}$

Hereditary erythrocytic multinuclearity associated with a positive acidified serum (Hams) test (HEMPAS) is a rare congenital dyserythropoetic anaemia. ${ }^{13}$ It is characterised by anaemia, episodes of jaundice, and splenomegaly. The bone marrow examination shows severe erythroid hyperplasia, with many of the erythroblasts containing two or more nuclei. The circulating red cells show moderate anisocytosis, anisochromia, and poikilocytosis. Reticulocyte counts are only minimally raised. Red cell life span is reduced to a mean of 18 days $^{13}$ (normal $>26$ days), but ineffective erythropoesis is clearly a major cause of the anaemia. ${ }^{14}$

Accepted for publication 16 April 1986
Serological abnormalities consist of an increased susceptibility of the red blood cells to agglutination by anti-i and lysis by anti-i and anti-I. The susceptibility to lysis of the red blood cells by some normal sera acidified to $\mathrm{pH} 6.8$ is a characteristic feature (emphasised in the name of the disorder).

Despite these abnormalities only about $25 \%$ of the patients described require transfusion support, most being only mildly anaemic. Aplastic crisis has not previously been associated with HEMPAS.

We report an acute human serum parvovirus infection associated with an abrupt fall in haemoglobin concentration and a lesser fall in white blood cells and platelets in a patient with HEMPAS.

\section{Case history}

HEMPAS was diagnosed in a woman aged 20. She had experienced intermittent attacks of jaundice for several years. The diagnosis was based on the characteristic appearance of the marrow, a positive Hams test with two of three normal sera (not her own serum), increased $i$ antigen on her red blood cells, and increased susceptibility to lysis with anti-I. She had a moderately enlarged spleen and in 1984 underwent cholecystectomy for pigment gallstones.

Over eight years of observation her haemoglobin concentration remained between 10 and $12 \mathrm{~g} / \mathrm{dl}$ without transfusion, except during pregnancy when transfusions were required. The white cell and platelet count were consistently within the normal range. Her reticulocyte count ranged from $2 \%$ to $4 \%$. Her red cell life span $\left(\mathrm{T}^{1 / 2}{ }^{51} \mathrm{Cr}\right)$ was estimated on four separate occasions, giving results of $11,12,15$, and 19 days (normal $>26$ days).

In July of 1985 she was admitted to hospital as an 
emergency. She had suffered abdominal pain, nausea, vomitting and diarrhoea for five days. She complained of progressive weakness.

On admission she had a fever of $38^{\circ} \mathrm{C}$, her haemoglobin was $5.3 \mathrm{~g} / \mathrm{dl}$, platelets $86 \times 10^{9} / 1$, and white cell count $1.7 \times 10^{9} / 1$. Reticulocytes were absent. Her bone marrow was mildly hypocellular with left shift of erythropoesis and a dearth of multinuclear cells, in sharp contrast to previous examinations of her marrow, which had shown severe hypercellularity, with increased erythropoesis and $30 \%$ of the erythroblasts being multinuclear.

She was transfused and her fever settled. Reticulocytes appeared in her peripheral blood reaching 5\% six days after admission. Her haemoglobin remained stable after this episode, and her platelet and white cell count returned to normal values.

Serum taken six and 31 days after admission was examined for human serum parvovirus specific IgM, according to the method of Cohen et al. ${ }^{9}$ Throat washings and urine collected nine days after admission were examined for the presence of human serum parvovirus DNA by dot blot DNA hybridisation using the method of Anderson et al. ${ }^{15}$

The serum samples contained 30 and 34 arbitrary units of antihuman parvovirus specific IgM and IgG antibody, respectively, six days after admission and $35 \mathrm{IgM}$ and $26 \mathrm{IgG}$ arbitrary units at 31 days after admission, indicating recent infection. Human serum parvovirus DNA was found neither in the urine or throat washings collected nine days after admission, nor in either serum sample.

\section{Discussion}

It seems likely that human serum parvovirus infection caused an aplastic crisis in this patient. Aplastic crises have been reported in both acquired and hereditary haemolytic anaemias. These have in common a shortened red cell survival so that aplasia in the bone marrow is rapidly reflected by a fall in peripheral haemoglobin concentration. It has been suggested that although there may be a direct infection of the erythroid precursors with the virus, ${ }^{1}$ aplasia of short duration (seven to 10 days) would pass unnoticed unless there were also shortened red cell survival. Our case supports this hypothesis, because although a major component of the anaemia of HEMPAS is caused by ineffective erythropoesis, our patient also had a shortened red cell survival.
As far as we know this has not been reported before in association with HEMPAS due to the rarity of this condition, and our case emphasises that anyone who has a shortened red cell survival may be susceptible to a aplastic crisis induced by parvovirus.

\section{References}

I Serjeant GT, Topley JM, Mason K, et al. Outbreak of aplastic crises in sickle cell anaemia associated with parvovirus-like agent. Lancet 1981;ii:595-8.

2 Pattison JR, Jones SE, Hodgson J, et al. Parvovirus infections and hypoplastic crises in sickle cell anaemia. Lancet 1981;i:664-5.

3 Green DH, Bellingham AJ, Anderson MJ. Parvovirus infection in a family associated with aplastic crisis in an affected sibling pair with hereditary spherocytosis. J Clin Pathol 1984;37: 1144-6.

4 Evans JPM, Rossiter MA, Kumaran TO, et al. Human parvovirus aplasia: case due to cross infection in a ward. $\mathrm{Br}$ Med J 1984;288:681.

5 Kelleher JF, Luban NLC, Mortimer PP, Kamimura T. Human serum "parvovirus": a cause of aplastic crisis in children with hereditary spherocytosis. J Pediat 1983;102:720-2.

6 Duncan JR, Cappellini MD, Anderson MJ, Potter CG, Kurtz JB, Weatherall JB. Aplastic crisis due to parvovirus infection in pyruvate kinase deficiency. Lancet 1983;ii:14-6.

7 Rao KR P, Patel AR, Anderson MJ, Hodgson J, Jones SE, Pattison JR. Infection with parvovirus-like virus and aplastic crisis in chronic haemolytic anaemia. Ann Intern Med 1983;98:930-2.

8 Mortimer PP. Hypothesis: the aplastic crisis of hereditary spero ocytosis is due to a single transmissible agent. $J$ Clin Patho 1983;36:445-8.

9 Cohen BJ, Mortimer PP, Pereira MS. Diagnostic assays witl? monoclonal antibodies for the human serum parvovirus-like virus (SPLV). J Hyg 1983;91:113-30.

10 Anderson MJ. The emerging story of a human parvovirus like agent. J Hyg 1982;89:1-8.

11 Plummer FA, Hammond GW, Forward K, et al. An erythema infectiosum-like illness caused by human parvovirus infection. N Engl J Med 1985;312:74-9.

12 Anderson MJ, Lewis E, Kidd IM, Hull SH, Cohen BJ. An outbreak of erythema infectiosum associated with human parvovirus infection. J Hyg 1984;93:85-93.

13 Verwilghen RL, Lewis SM, Dacie JV, Crookson JH, Crookson MC. HEMPAS: congenital dyserythropoetic anaemia. (type II) $Q J$ Med 1973;XLII:257-78.

14 Valentine WN, Crookston JH, Paglia DE, Konrad PN. Erythrocytic enzymatic abnormalities in HEMPAS (hereditary erythroblastic multinuclearity with a positive acid serum test). $\mathrm{Br} J$ Haematal 1972;23:107-11.

15 Anderson MJ, Jones SE, Minson AC. Diagnosis of human parvovirus infection by dot-blot hybridisation using cloned viral DNA. J Med Virol 1985;15:163-72.

Requests for reprints to: Dr NC West, Department of Pathology, West Cumberland Hospital, Hensingham, Whitehaven, Cumbria CA28 8JG, England. 